\title{
IMPLEMENTASI VIRTUAL PRIVATE NETWORK - WAN DALAM DUNIA BISNIS
}

\author{
Darma Oktavia \\ 185100020 , Sistem Informasi \\ Fakultas Komputer \\ darmaoktavia.students@umitra.ac.id
}

\begin{abstract}
Dalam dunia bisnis, biasanya sebuah organisasi ingin membangun Wide Area Network(WAN) untuk menghubungkan beberapa kantor cabangnya. Sebelum munculnya Virtual Private Network (VPN), mereka umumnya menggunakan " leased line" yang mahal sehingga hanya perusahaan besar yang dapat memilikinya.

VPN - WAN memberi solusi alternatif karena dapat mengurangi biaya pembuatan infrastruktur jaringan dan memotong biaya operasional dengan memanfaatkan failitas internet sebagai media komunikasinya. Perusahaan cukup menghubungi Internet Service Provider (ISP) terdekat untuk mendapatkan layanan ini.Setiap paket informasi yang dikirim dapat diakses, diawasi atau bahkan dimanipulasi oleh pengguna. Supaya komunikasi berjalan aman maka diperlukan protokol tambahan khusus yang dirancang untuk mengamankan data yang dikirim. Dewasa ini sudah banyak perusahaan seperti : perusahaan manufaktur, distribusi dan retail; pertambangan minyak dan gas, telekomunikasi, finansial, pemerintahan serta industri transportasi yang menggunakan VPN karena fasilitas -fasilitas yang ditawarkan berupa remote access client, internetworking LAN to LAN serta akses yang terkontrol dengan biaya yang murah. Uji coba yang dilakukan Miercom(LAB penyedia testing kinerja perangkat keras) terhadap Cisco 1841 membuktikan bahwa Cisco 1841 dapat menopang suatu komunikasi dua arah, interkoneksi IP WAN kapasitas E1 dengan enkripsi 3DES yang dapat menunjang throughput sampai dengan 2 Mbps dalam koneksi E1 IP-WAN.

Penggunaan VPN akan meningkatkan efektivitas, efisiensi kerja serta skalabilitas perusahaan. Keuntungan lain yang didapat dari VPN adalah pada biaya pulsa yang jauh lebih murah dibandingkan dengan menggunakan" leased line”.
\end{abstract}

Kata Kunci: VPN, WAN, paket informasi, ISP, remote access client, skalabilitas. 


\section{A. PENDAHULUAN}

Dewasa ini dalam kehidupan dunia yang semakin maju di segala bidang termasuk pula perkembangan teknologi yang sangat pesat dan berdampak pada kehidupan peradaban dunia saat ini. Semua saling berlomba untuk mengembangkan diri untuk mencapai perkembangan hasil yang semakin baik dari hari ke hari. Perkembangan yang pesat dalam bidang Teknologi Informasi baik dalam bidang sistem manajemen, sistem ketenagakerjaan maupun dalam bidang komputerisasi, menyebabkan munculnya banyak peralatan dengan menggunakan prinsip dasar pengiriman data dengan piranti yang tentu saja semakin kreatif dan inovatif disesuaikan dengan kebutuhan zaman. Hal inilah yang menyebabkan pemerintah maupun swasta mulai mengembangkan pengetahuan tentang komunikasi data dengan menggunakan jaringan baik menggunakan kabel maupun tanpa kebel. WAN merupakan salah satu jenis jaringan yang mempunyai jangkauan jaringan yang luas dan sangat cepat karena menggunakan media transmisi salelit, maupun telepon. Karena teknologi WAN yang sudah modern, maka banyak hal-hal yang harus dipelajari dan dimengerti, sehingga permasalahan yang dihadapi diantaranya adalah: 1 . Bagaimana mengimplementasikan WAN di dunia bisnis 2. Bagaimana melakukan setting terhadap WAN.

B. PEMBAHASAN / STUDI KASUS

Wide Area Network (WAN) merupakan jaringan komputer yang saling berjauhan dan mencakup daerah geografis yang luas, seringkali mencakup sebuah negara atau benua. Dalam melaksanakan koneksinya WAN seringkali menggunakan satelit sebagai media perantara, akan tetapi WAN juga bisa menggunakan koneksi antar router yang biasa disebut dengan point-to-poin. Pada subnet point-to-point, masalah rancangan yang penting adalah pemilihan jenis topologi interkoneksi router (Cisco, 2004).

\section{IMPLEMENTASI WAN} Sering kali kita menyebut komputer client sebagai host. Host dihubungkan dengan sebuah subnet komunikasi, atau cukup disebut subnet. Tugas subnet adalah membawa pesan dari host ke host lainnya, seperti halnya sistem telepon yang membawa isi pembicaraan dari pembicara ke pendengar. 
Dengan memisahkan aspek komunikasi murni sebuah jaringan (subnet) dari aspekaspek aplikasi (host), rancangan jaringan lengkap menjadi jauh lebih sederhana.

Pada sebagian besar WAN, subnet terdiri dari dua komponen, yaitu kabel transmisi dan elemen switching. Kabel transmisi (disebut juga sirkuit, channel, atau trunk) memindahkan bit-bit dari satu mesin ke mesin lainnya. Element switching adalah komputer khusus yang dipakai untuk menghubungkan dua kabel transmisi atau lebih. Saat data sampai ke kabel penerima, element switching harus memilih kabel pengirim untuk meneruskan pesan-pesan tersebut. Jenis - jenisnya sangat bervariasi diantaranya yaitu packet switching node, intermidiate system, serta data switching exchange. Setiap host dihubungkan ke LAN tempat dimana terdapat sebuah router (komputer switching). Dalam beberapa keadaan tertentu sebuah host dapat dihubungkan langsung ke sebuah router. Kumpulan saluran komunikasi dan router akan membentuk subnet.

Pada sebagian besar WAN, jaringan terdiri dari sejumlah banyak kabel atau saluran telepon yang menghubungkan sepasang router. Bila dua router yang tidak mengandung kabel yang sama akan melakukan komunikasi, keduanya harus berkomunikasi secara tak langsung melalui router lainnya. Ketika sebuah paket dikirimkan dari sebuah router ke router lainnya melalui router perantara atau lebih, maka paket akan diterima router dalam keadaan lengkap, disimpan sampai saluran output menjadi bebas, dan kemudian baru diteruskan. Subnet yang mengandung prinsip seperti ini disebut subnet point-to-point, store-and-forward, atau packetswitched. Hampir semua WAN (kecuali yang menggunakan satelit) memiliki subnet storeand-forward.

\section{ID SECURITY} QWTD4452377-ASP-5244166

\section{KESIMPULAN}

Kesimpulan yang dapat diambil dari implementasi Virtual Private Network - WAN diantaranya adalah:

1. Secara umum hardware yang digunakan dalam mengaplikasikan WAN adalah workstation, servers, bridge, router, switch, hub.

2. Router yang saling berkoneksi dan saling mengirim dan menerima dalam satu jaringan atau lebih disebut sistem point-to-point, storeandforward, atau packet-switched.

\section{E. DISKUSI}

Saya bersama teman saya bernama Andeansyah mendiskusikan dengan baik mengenai Server yang berbentuk pada aplikasi Cloud untuk memudahkan mahasiswa dan kampus mengakses data 
pribadi yang dapat disimpulkan sebagai berikut :

1. Cloud computating ialah aplikasi yang dapat memudahkan kampus atau mahasiswa dalam mengakses data pribadi dimana pun berada.

2. Aplikasi Cloud ini pun mempermudah mahasiswa maupun kampus karena aplikasi ini tidak memerlukan device maupun pc dengan spesifikasi tinggi karena aplikasi ini dapat diakses melalui Chrome, Mozilla, Internet explorer.

\section{F. REFERENCE}

[1] O. M. Febriani and A. S. Putra, "Sistem Informasi Monitoring Inventori Barang Pada Balai Riset Standardisasi Industri Bandar Lampung," J. Inform., vol. 13, no. 1, pp. 90-98, 2014.

[2] A. S. Putra, "Paperplain: Execution Fundamental Create Application With Borland Delphi 7.0 University Of Mitra Indonesia," 2018.

[3] A. S. Putra, "2018 Artikel Struktur Data, Audit Dan Jaringan Komputer," 2018.

[4] A. S. Putra, "ALIAS 


MANAGER USED IN
DATABASE
STUDI CASE DB DEMOS."

[5] A. S. Putra, "COMPREHENSIVE SET OF PROFESSIONAL FOR DISTRIBUTE COMPUTING."

[6] A. S. Putra, "DATA ORIENTED RECOGNITION IN BORLAND DELPHI 7.0."

[7] A. S. Putra, "EMBARCADERO DELPHI XE 2 IN GPUPOWERED FIREMONKEY APPLICATION."

[8] A. S. Putra, "HAK ATAS KEKAYAAN INTELEKTUAL DALAM DUNIA TEKNOLOGY BERBASIS REVOLUSI INDUSTRI 4.0."

[9] A. S. Putra, "IMPLEMENTASI PERATURAN

PERUNDANGAN UU. NO 31

TAHUN 2000 TENTANG DESAIN INDUSTRI BERBASIS INFORMATION TECHNOLOGY."

[10] A. $\quad$ S. $r$ Putra, PARADOX DBASE."

[11] A. S. Putra, "IMPLEMENTATION OF TRADE SECRET CASE STUDY SAMSUNG MOBILE PHONE."

[12] A. S. Putra, "IMPLEMENTATION PATENT FOR APPLICATION WEB BASED CASE STUDI WWW. PUBLIKLAMPUNG. COM."

A. S. Putra, "IMPLEMENTATION SYSTEM FIRST TO INVENT IN DIGITALLY INDUSTRY."

[14] A. S. Putra, "MANUAL
REPORT \& INTEGRATED DEVELOPMENT

ENVIRONMENT BORLAND DELPHI 7.0."

[15] A. S. Putra, "PATENT AS RELEVAN SUPPORT RESEARCH."

[16] A. S. Putra, "PATENT FOR RESEARCH STUDY CASE OF APPLE. Inc."

[17] A. S. Putra, "PATENT PROTECTION FOR APPLICATION INVENT."

[18] A. S. Putra, "QUICK REPORT IN PROGRAMMING."

[19] A. S. Putra, "REVIEW CIRCUIT LAYOUT COMPONENT

REQUIREMENT ON ASUS NOTEBOOK."

[20] A. S. Putra, "REVIEW TRADEMARK PATENT FOR INDUSTRIAL TECHNOLOGY BASED 4.0."

[21] A. S. Putra, "TOOLBAR COMPONENT PALLETTE IN OBJECT ORIENTED PROGRAMMING."

[22] A. S. Putra, "WORKING DIRECTORY SET FOR PARADOX 7."

[23] A. S. Putra, "ZQUERY CONNECTION

IMPLEMENTED

PROGRAMMING STUDI CASE PT. BANK BCA Tbk."

[24] A. S. Putra, D. R. Aryanti, and I. Hartati, "Metode SAW (Simple Additive Weighting) sebagai Sistem Pendukung Keputusan Guru Berprestasi (Studi Kasus: SMK Global Surya)," in Prosiding Seminar Nasional Darmajaya, 2018, vol. 1, no. 1, 
pp. 85-97.

[25] A. S. Putra and O. M. Febriani, "Knowledge Management Online Application in PDAM Lampung Province," in Prosiding International conference on Information Technology and Business (ICITB), 2018, pp. 181-187.

[26] A. S. Putra, O. M. Febriani, and B. Bachry, "Implementasi Genetic Fuzzy System Untuk Mengidentifikasi Hasil Curian Kendaraan Bermotor Di Polda Lampung," SIMADA (Jurnal Sist. Inf. dan Manaj. Basis Data), vol. 1, no. 1, pp. 21-30, 2018.

[27] A. S. Putra, H. Sukri, and K. Zuhri, "Sistem Monitoring Realtime Jaringan Irigasi Desa (JIDES) Dengan Konsep Jaringan Sensor Nirkabel," IJEIS (Indonesian J. Electron. Instrum. Syst., vol. 8, no. 2, pp. 221-232.

[28] D. P. Sari, O. M. Febriani, and A. S. Putra, "Perancangan Sistem Informasi SDM Berprestasi pada SD Global Surya," in Prosiding Seminar Nasional Darmajaya, 2018, vol. 1, no. 1, pp. 289-294. 